Original

\title{
Proliferative activity in oral salivary gland tumors: the role of PCNA and AgNOR assessed by a double staining technique
}

\author{
Elena Riet Correa Rivero ${ }^{\S}$, Marcelo Vidigal Caliari ${ }^{\dagger}$, Sandra Beatriz Chaves Tarquínio ${ }^{\ddagger}$, \\ Adriano Mota Loyola* and Maria Cássia Ferreira de Aguiar ${ }^{\S}$

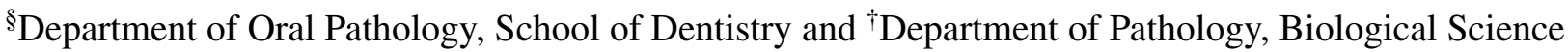 \\ Institute, Minas Gerais Federal University, Belo Horizonte, Brazil \\ \#epartment of Oral Pathology, School of Dentistry, Pelotas Federal University, Pelotas, Brazil \\ *Department of Oral Pathology, School of Dentistry, \\ Uberlândia Federal University, Uberlândia, Brazil
}

(Received 22 May 2003 and accepted 18 February 2004)

\begin{abstract}
The aim of this study was to evaluate the role of PCNA and AgNOR in the assessment of salivary gland tumor proliferation using a double staining technique. Ten cases of pleomorphic adenoma (PA) and seventeen cases of adenoid cystic carcinoma (ACC) were examined. Numeric and morphometric parameters of AgNOR were evaluated and compared in PCNA-positive and PCNA-negative nuclei. There were statistically significant differences in AgNOR numbers, perimeters and contour indices between PCNA-positive and -negative nuclei in the PA samples. The ACC samples demonstrated significant differences only in the AgNOR areas. Our results show that in salivary gland tumors there is not always a relationship between proliferative activity evaluated by AgNOR numeric and morphometric parameters and PCNA immunostaining. (J. Oral Sci. 46, 87-92, 2004)
\end{abstract}

Key words: AgNOR; adenoid cystic carcinoma; double staining technique; PCNA, pleomorphic adenoma; proliferation markers.

Correspondence to Dr. Maria Cássia Ferreira de Aguiar, Department of Oral Pathology, School of Dentistry, Federal University of Minas Gerais (UFMG), Av. Antônio Carlos, 6627 - Pampulha, CEP 31270-901 - Belo Horizonte - Minas Gerais, Brazil

Tel: +55 $313499-2476$

Fax: +55 $313499-2472$

E-mail: mcaguiar@odonto.ufmg.br

\section{Introduction}

PCNA (proliferating cell nuclear antigen) and AgNOR (silver-staining nucleolar organizer region) have been used as additional aids to obtaining prognostic information about salivary gland tumors besides the classical clinicopathological indicators (1-3). In the majority of previous studies, these markers were evaluated separately.

PCNA is a nonhistone nuclear protein that functions as a cofactor for DNA polymerase-delta and plays a role in the initiation of cell proliferation (4). PCNA immunohistochemistry appears to have predictive significance in the evaluation of salivary tumors $(2,5)$ although some conflicting results have been reported (6).

The AgNORs are a set of proteins associated with segments of DNA that transcribe to ribosomal RNA. These proteins are defined as markers of "active" ribosomal genes $(7,8)$. Previous studies of AgNORs as indicators of precise proliferative status have sometimes resulted in ambiguity (9). In salivary gland tumors, studies have most frequently addressed the prognosis of neoplasms with the aim of using AgNORs to distinguish between benign and malignant tumors (10-13). However, AgNORs appear to be of little value in estimating the prognosis of salivary gland malignancies (14).

Pleomorphic adenoma (PA) and adenoid cystic carcinoma (ACC) are common tumors which involve both the major and minor salivary glands. Although both tumors originate in the intercalated duct with the same cellular derivation (15) and secretion of proteins of the extracellular 
matrix (16), they exhibit the characteristic behavior of benign and malignant tumors, respectively, coupled with distinct proliferative activity (17-20)

The objective of this study was to evaluate the role of PCNA and AgNOR in the assessment of salivary gland tumor proliferation using a double staining technique.

\section{Materials and Methods}

Formalin-fixed paraffin-embedded tissue specimens from 10 pleomorphic adenomas and 17 adenoid cystic carcinomas of the minor oral salivary glands were selected from the files of the Oral Pathology Department of the Federal University of Minas Gerais, Federal University of Uberlândia and Federal University of Pelotas (Brazil). Histopathological diagnosis was undertaken based on hematoxylin-eosin-stained sections. There were five solid, six tubular and six cribriform ACCs.

\section{Double staining technique}

Sections were cut at $3 \mu \mathrm{m}$ thickness. The slides were deparaffinized, hydrated and immersed in citric acid (10 $\mathrm{mM})$ at $\mathrm{pH} 6.0$, then heated in a microwave oven at 700 $\mathrm{W}$ in three cycles of $5 \mathrm{~min}$ each for antigenic retrieval.

The primary antibody, anti-PCNA (PC10, Dako Corporation; Glostrub, Denmark), was incubated with the sections at $1: 100$ dilution for $18 \mathrm{~h}$ at $4^{\circ} \mathrm{C}$. The sections were then thoroughly rinsed and exposed to the secondary antibody (Biogenex, San Ramon, CA, USA) for $30 \mathrm{~min}$ at room temperature. After further washing, the sections were exposed to alkaline phosphatase-conjugated streptavidin (Biogenex, San Ramon, CA, USA) for 30
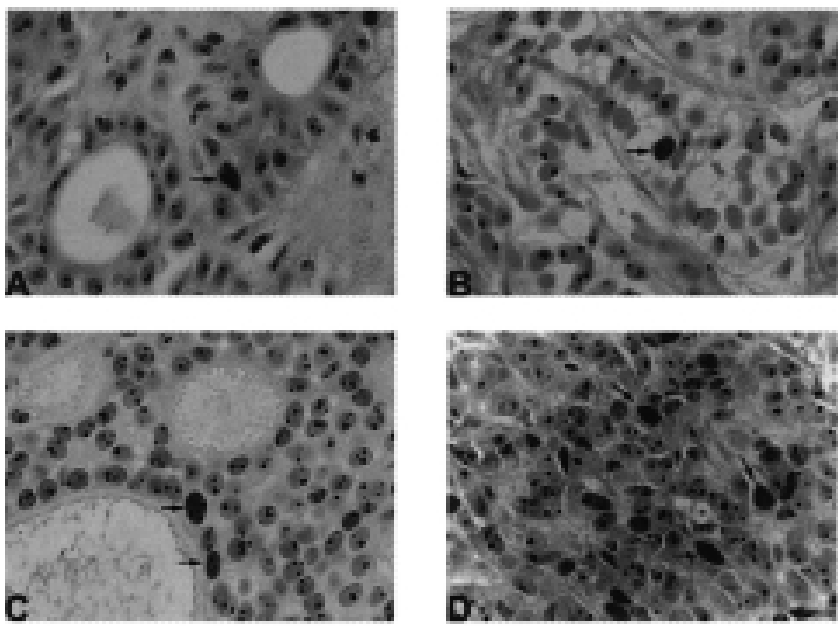

Fig. 1 PCNA/AgNOR double staining in pleomorphic adenoma (A) in adenoid cystic carcinoma: tubular (B), cribriform (C) and solid (D). The AgNORs are shown as black dots within the nuclei of PCNA-positive (arrows) and PCNA-negative cells. min at room temperature. Freshly made fuchsin (New fuchsin: Biogenex, San Ramon, CA, USA) was used as the chromogen for $30 \mathrm{~min}$ in the dark at room temperature. No nuclear counterstaining was done. Negative controls were incubated in buffer without primary antibody.

Silver staining was applied according to the method of Ploton et al. (21), with some modifications. In brief, the final working solution was freshly made by mixing one volume of $2 \%$ gelatin in $1 \%$ formic acid solution and two volumes of $50 \%$ aqueous silver nitrate solution. Slides were incubated in this solution for $25 \mathrm{~min}$ in the dark at room temperature, washed with deionized water at $45^{\circ} \mathrm{C}$, washed in running deionized water for $15 \mathrm{~min}$, dehydrated, cleaned and mounted in Permount ${ }^{\circledR}$ (Fischer Scientific, Fair Lawn, NJ, USA).

Quantitative and morphometric parameters of the AgNORs were performed using image-processing software (KS-300; Kontron Elektronic/Carl Zeiss). The sections were examined at $\times 1000$ magnification. For each case, 100 PCNA-positive cells and 100 PCNA-negative cells were examined. The nucleus was considered positive for PCNA only if there was an unequivocal red reaction product. The morphometric parameters considered were area, perimeter and contour index (CI) for each AgNOR.

Mean numbers per nucleus, area, perimeter and contour index of AgNORs were calculated for PCNA-positive and PCNA-negative nuclei. The contour index of an AgNOR is an expression of shape irregularities (the minimum value of 3.544 corresponds to a perfect circle). Student's paired t-test was used to compare the AgNOR parameters of PCNA-positive and -negative cells when the sample was normal, and the Mann-Whitney test when the sample was not normal, using the Sigma Stat Program. Differences at $P<0.05$ were considered significant.

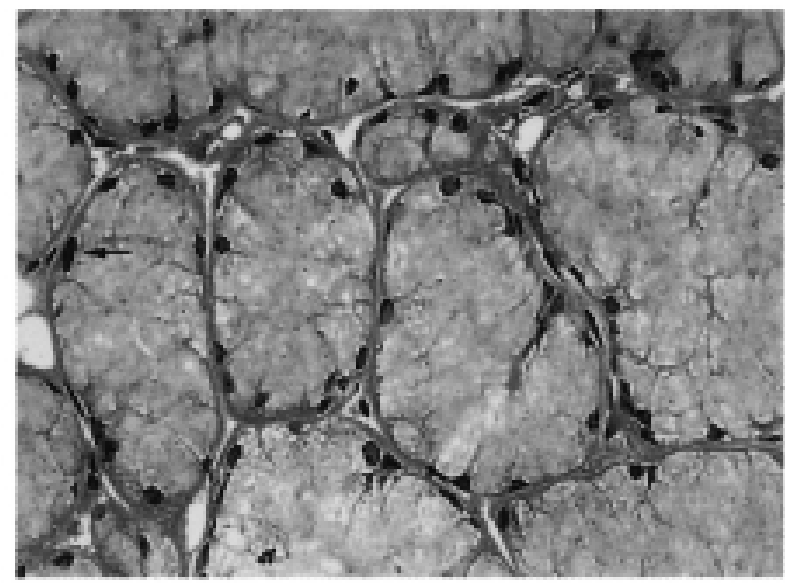

Fig. 2 PCNA/AgNOR double staining in normal salivary gland (arrow). AgNOR counts vary between one and two per nuclei. 
Table 1 Mean AgNOR scores in PCNA-positive and PCNA-negative cells

\begin{tabular}{|c|c|c|c|c|c|c|c|c|c|c|c|c|c|c|}
\hline & \multicolumn{7}{|c|}{ PA } & \multicolumn{7}{|c|}{$\mathrm{ACC}$} \\
\hline & \multicolumn{3}{|c|}{ Positive } & \multicolumn{4}{|c|}{ Negative } & \multicolumn{3}{|c|}{ Positive } & \multicolumn{4}{|c|}{ Negative } \\
\hline & Min & Max & $\mathrm{X} \pm \mathrm{SEM}$ & Min & Max & $\mathrm{X} \pm$ SEM & $P$ value & Min & Max & $\mathrm{X} \pm \mathrm{SEM}$ & Min & Max & $\mathrm{X} \pm \mathrm{SEM}$ & $P$ value \\
\hline Number & 1.68 & 2.29 & $1.97 \pm 0.20$ & 1.33 & 1.72 & $152 \pm 0.11$ & $<0.0001^{*}$ & 1.35 & 2.65 & $2.14 \pm 0.37$ & 1.29 & 2.79 & $1.97 \pm 0.37$ & $0.25^{1}$ \\
\hline Area & 1.03 & 1.88 & $1.38 \pm 0.26$ & 0.9 & 1.67 & $1.22 \pm 0.21$ & $0.13^{1}$ & 0.9 & 2.27 & 1.21 & 0.68 & 2.29 & 1.06 & $0.02^{2 *}$ \\
\hline Perimeter & 4.61 & 6.22 & $5.44 \pm 0.49$ & 3.84 & 5.48 & $4.87 \pm 0.49$ & $0.02^{1 *}$ & 4.15 & 7.04 & 4.96 & 3.52 & 6.56 & 4.54 & $0.09^{2}$ \\
\hline $\begin{array}{l}\text { Contour } \\
\text { index }\end{array}$ & 0.49 & 0.69 & $0.59 \pm 0.05$ & 0.57 & 0.76 & $0.66 \pm 0.07$ & $0.02^{1 *}$ & 0.55 & 0.73 & $0.63 \pm 0.05$ & 0.56 & 0.76 & $0.66 \pm 0.06$ & $0.07^{1}$ \\
\hline
\end{tabular}

\author{
Min: Minimum \\ Max: Maximum \\ SEM (standard error of mean) \\ ${ }^{1}$ Student's $t$ test \\ ${ }^{2}$ Mann-Whitney test \\ $*_{\text {Significant difference }}(P<0.05)$
}

\section{Results}

A positive reaction to the PCNA antibody was revealed as intense red staining with a granular pattern limited to the cell nucleus. The AgNORs were interpreted as black dots within the cell nucleus (Fig. 1). In normal salivary gland tissue present in the specimens (internal control), PCNA-positive cells were rare and the AgNOR counts per nucleus varied between one and two (Fig. 2).

The AgNOR count per nucleus in the PA samples was higher in PCNA-positive than in PCNA-negative cells. The same result was found for the ACC samples; however, significant differences were observed only for AP (Table 1).

In the PA samples, the perimeter and area of the AgNORs were higher in PCNA-positive than in PCNA-negative cells. The CI was smaller in cells immunolabelled by PC10. There was also a significant difference in the perimeter and CI of AgNORs between PCNA-positive and PCNA-negative nuclei in the PA samples. In the ACC samples significant difference between PCNA-positive and -negative cells was found only in the AgNOR areas (Table 1).

In the ACC samples, double staining showed the same pattern among solid, tubular and cribriform types, although a higher number of PCNA-positive cells were demonstrated in some cases of solid ACC.

\section{Discussion}

Prior to this investigation, studies employing PCNA or AgNOR techniques for evaluation of the proliferative activity of salivary gland tumors have assessed these markers separately. The co-localization of AgNOR and PCNA in the tissue through double labeling allows them to be analyzed in the same cell and provides a method to directly assess the relationship between these markers, overcoming the problem of neoplasm heterogeneity (22).

The present study showed a higher mean number of AgNORs in PCNA-positive than in PCNA-negative cells in the PA samples. Others studies have also shown concordance between PCNA and AgNORs (22-24). This result is also in agreement with others studies showing the capacity of both PCNA and AgNOR number of discrimination of a higher proliferative activity in solid/ductal areas than that in myxomatous/chondroid areas in AP (25-27).

However we did not find any positive relationship between PCNA and AgNORs when we analyzed only the numeric index of AgNORs in the ACC samples. Other studies have also noted a lack of correlation between these indices when analyzed separately in other kinds of tumors (28-32) . The inadequacy of statistical correlations between the PCNA index and AgNOR counts has been attributed to the fact that these methods quantify different aspects of proliferative activity.

PCNA is correlated with the S-phase of the cell cycle and plays a critical role in the initiation of cell proliferation $(4,33,34)$. However, the long half-life of the protein leads to labeling of cells that have already left the cell cycle (35). PCNA staining may also occur in non-S-phase cells engaged in nucleotide excision DNA repair (36). Despite the diverse roles played by the PCNA protein, there is evidence for deregulated overexpression in some types of 
salivary gland tumors with a prognostic significance (5).

On the other hand, quantitative analysis of interphase NORs has proved to be valuable in tumor pathology for distinguishing malignant from benign lesions of the same origin $(37,38)$ and has been used to discriminate between benign and malignant salivary gland tumors (10-13). Vuhuhula et al. (1) correlated the mean AgNOR count with the biological behavior of ACC and speculated that AgNOR may be more indicative of the biological nature of the condition and hence the degree of malignancy, rather than its proliferative status. Fonseca et al. (14) concluded that in ACC, AgNOR counts do not seem to be a prognostic indicator, in contrast to the usefulness of this method in other tumor types.

The "paradoxical" AgNOR results, i.e. the absence of a relationship between AgNOR number and the PCNA index in ACC, should be also related to the demonstration of cellular metabolic activity of the cells by silver staining. The AgNOR number in ACC could reflect metabolic activity rather than changes in proliferative activity. In 2002, Dayan et al. (39), studying the effects of age on the proliferative capacity of acinar and ductal cells, demonstrated this intricate relationship.

Morphometric and quantitative analyses of AgNORs in malignant tumor cells show large numbers in the nucleus, small in size, and with a scattered distribution and irregular shape, compared with benign tumors cells (40). The disorganized AgNORs may be associated with active NORs or dispersion of multiple nucleoli, resulting in bizarre shapes and large irregular NOR aggregates. In this work, for the PA samples, the perimeter and area of the AgNORs were higher and the CI was smaller in PCNApositive cells than in PCNA-negative cells. However, a statistically significant difference was observed only for perimeter and CI. These differences may be the result of a more clustered distribution of NORs in PCNA-positive than in negative ones.

The unique parameter of AgNORs in the ACC samples that showed a statistically significant difference between PCNA-positive and PCNA-negative cells was the mean AgNOR area, which was significantly higher in the immunolabelled cells. Other studies that used a double staining technique for AgNOR and Ki-67 (MIB-1) also found higher mean AgNOR areas in the Ki-67-positive cells $(41,42)$. Some authors have pointed out that measurement of AgNOR area using an image analysis method is the best indicator and the most reproducible parameter of the AgNOR index (43-45) and could be a substitute for AgNOR quantification that should be restricted to cases that exhibit cells with distinct silver stained dots.

Leek et al. (9), studying cellular proliferation in different tissues, showed that an increase in the size of AgNOR clusters rather than their number correlated positively with elevated labeling by BrdUrd. In the ACC samples, the increased AgNOR area may also reflect an increased rate of proliferative activity rather than AgNOR number.

Although this work seems to suggest different roles for PCNA and AgNOR in the evaluation of cellular proliferation in salivary gland tumors, other studies are necessary to confirm this view.

\section{Acknowledgments}

This study was funded by the Conselho Nacional de Desenvolvimento Científico e Tecnológico (CNPq). CNPq 300410/98-0.

\section{References}

1. Vuhahula EA, Nikai H, Ogawa I, Miyauchi M, Tanaka T, Ito H, Ito R (1995) Correlation between argyrophilic nucleolar organizer region (AgNOR) counts and histologic grades with respect to biologic behavior of salivary adenoid cystic carcinoma. J Oral Pathol Med 24, 437-442

2. Zhu Q, White FH, Tipoe GL (1997) The assessment of proliferating cell nuclear antigen (PCNA) immunostaining in human benign and malignant epithelial lesions of the parotid gland. Oral Oncology 33, 29-35

3. Cho KJ, Lee SS, Lee YS (1999) Proliferating cell nuclear antigen and c-erbB-2 oncoprotein expression in adenoid cystic carcinomas of the salivary glands. Head Neck 21, 414-419

4. Bravo R, Macdonald-Bravo H (1987) Existence of two populations of cyclin/proliferating cell nuclear antigen during the cell cycle: association with DNA replication sites. J Cell Biol 105, 1549-1554

5. Trendell-Smith NJ, Oates J, Crocker J (1997) The evaluation of salivary gland tumours using proliferating cell nuclear antigen. J Laryngo Otol. 111, 551-555

6. Zhao M, Zhao QX, Saitoh M et al (1996) Proliferating patterns of salivary gland adenocarcinomas with the use of PCNA labeling. Anticancer Res 16, 2693-2698

7. Goodpasture C, Bloom SE (1975) Visualization of nucleolar organizer regions in mammalian chomosomes using silver staining. Chromosom 53, 37-50

8. Howell WM, Black DA (1980) Controlled silverstaining of nucleolus organizer regions with a protective colloidal developer: a I-step method. Experientia 36, 1014-1015 
9. Leek RD, Alison MR, Sarraf CE (1991) Variations in the occurrence of silver-staining nucleolar organizer regions (AgNORs) in non-proliferating and proliferating tissues. J Pathol 165, 43-51

10. Matsumura K, Sasaki K, Tsuji T, Shinozaki F (1989) The nucleolar organizer regions associated protein (Ag-NOR) in salivary gland tumors. Int J Oral Maxillfac Surg 18, 76-78

11. Van Heerden WFP, Raubenheimer EJ (1991) Evaluation of the nucleolar organizer region associated proteins in minor salivary gland tumors. J Oral Pathol Med 20, 291-295

12. Cardillo MR (1992) AgNOR technique in fine needle aspiration cytology of salivary gland masses. Acta Cytologica 36, 147-151

13. Epitavianos A, Trigonidis G (1994) Salivary gland tumors studied by means of the AgNOR technique. Ann Dent 53, 21-25

14. Fonseca I, Soares J (1993) Adenoid cystic carcinoma: a study of nucleolar organizer regions (AgNOR) counts and their relation to prognosis. J Pathol 169, 255-258

15. de Araujo VC, de Sousa SO, Carvalho YR, de Araujo NS (2000) Application of immunohistochemistry to the diagnosis of salivary gland tumors. Appl Immunohistochem Mol Morphol 8, 195-202

16. Nara Y, Takeuchi J, Yoshida K, Fukatsu T, Nagasaka T, Kawaguchi T, Meng N, Kikuchi H, Nakashima N (1991) Immunohistochemical characterisation of extracellular matrix components of salivary gland tumours. Br J Cancer 64, 307-314

17. Saka T, Yamamoto Y, Takahashi H (1991) Comparative cytofluorometric DNA analysis of pleomorphic adenoma and adenoid cystic carcinoma of the salivary glands. Virchows Arch B Cell Pathol $61,255-261$

18. Giannoni C, el-Naggar AK, Ordonez NG, Tu ZN, Auatin J, Luna MA, Batsakis JG (1995) C-erbB2/neu oncogene and Ki-67 analysis in the assessment of palatal salivary gland neoplasms. Otolaryngol Head Neck Surg 112, 391-398

19. Daniele E, Tralongo V, Morello V, Nagar C, Russo A, Bazan V, Dardanoni G, Ciotta S, Nuara R, Tomasino RM (1996) Pleomorphic adenoma and adenoid-cystic carcinoma of salivary glands: immunohistochemical assessment of proliferative activity in comparison with flow-cytometric study. Cell Prolif 29, 153-162

20. Zhu Q, Tipoe GL, White FH (1999) Proliferative activity as detected by immunostaining with Ki-67 and proliferating cell nuclear antigen in benign and malignant epithelial lesions of the human parotid gland. Anal Quant Cytol Histol 21, 336-342

21. Ploton D, Menager M, Jeannesson P, Himber G, Piegeon F, Adnet JJ (1986) Improvement in the staining and in the visualization of the argyrophilic proteins of the nucleolar organizer region at the optical level. Histochem J 18, 5-14

22. Smith FG, Murray PG, Crocker J (1993) Correlation between PCNA and AgNOR scores in nonHodgkin's lynphomas using sequential staining technique. J Clin Pathol 46, 28-31

23. Costa ALL, Araújo NS, Pinto Jr.DS, Araújo VC (1999) PCNA/AgNOR and Ki-67/AgNOR double staining in oral squamous cell carcinoma. J Oral Pathol Med 28, 438-441

24. Moreira Leite, KR, de Araujo VC, Rezende Meirelles MI, Lopes Costa AD, Camara-Lopes LH (1999) No relationship between proliferative activity and the macis prognostic scoring system in papillary thyroid carcinoma. Head Neck 21, 602-605

25. Landini G (1990) Nucleolar organizing regions (NORs) in pleomorphic adenomas of the salivary glands. J Oral Pathol Med 19, 257-260

26. Fujita S, Takahashi H, Okabe H (1992) Proliferative activity in normal salivary gland and pleomorphic adenoma. A study by argyrophilic nucleolar organizer region (AgNOR) staining. Acta Pathol Jpn 42, 573-578

27. Ogawa I, Miyauchi M, Takata T, Vuhahula E, Ijuhin N, Nikai H (1993) Proliferative activity of salivary gland pleomorphic adenomas and myoepitheliomas as evaluated by the proliferating cell nuclear antigen (PCNA) labeling index (LI). J Oral Pathol Med 22, 447-450

28. Yu CC, Fletcher CD, Newman PL, Goodlad JR, Burton JC, Levison DA (1992) A comparison of proliferating cell nuclear antigen (PCNA) immunostaining, nucleolar organizer region (AgNOR) staining, and histological grading in gastrointestinal stromal tumours. J Pathol 166, 147152

29. Evans AT, Blessing K, Orrell JM, Grant A (1992) Mitotic indices, anti-PCNA immunostaining, and AgNORs in thick cutaneous melanomas displaying paradoxical behavior. J Pathol 168, 15-22

30. Ghazizadeh M, Sasaki Y, Araki T, Konishi H, Aihara K (1997) Prognostic value of proliferative activity of ovarian carcinoma as revealed by PCNA and AgNOR analyses. Am J Clin Pathol 107, 451-458 31. Irazusta SP, Vassalo J, Magna LA, Metze K, Trevisan 
M (1998) The value of PCNA and AgNOR staining in endoscopic biopsies of gastric mucosa. Pathol Res Pract 194, 33-39

32. Mesquita RA, Sousa SCOM, Araújo NS (1998) Proliferative activity in peripheral ossifying fibroma and ossifying fibroma. J Oral Pathol Med 27, 6467

33. Bravo, R (1986) Synthesis of the nuclear protein cyclin (PCNA) and its relationship with DNA replication. Exp Cell Res 163, 287-293

34. Prelich G, Tan CK, Kostura M et al (1987) Functional identity of proliferating cell nuclear antigen and a DNA polymerase- $\delta$ auxiliary protein. Nature. 326 , 517-520

35. Scott RJ, Hall PA, Haldane JS et al (1991) A comparison of immunohistochemical markers of cell proliferation with experimentally determined growth fraction. J Pathol 165, 173-178

36. Shivji MKK, Kenny MK, Wood RD (1992) Proliferating cell nuclear antigen is required for DNA excision repair. Cell 69, 367-374

37. Derenzini M (2000) The AgNORs. Micron 31, 117120

38. Cabrini RL, Schwint AE, Mendez A, Femopase F, Lanfranchi H, Itoiz ME (1992) Morphometric study of nucleolar organizer regions in human oral normal mucosa, papilloma and squamous cell carcinoma. J Oral Pathol Med 21, 275-279

39. Dayan D, Vered M, Sivor S, Hiss Y, Buchner A (2002) Age-related changes in proliferative markers in labial salivary glands: a study of argyrophilic nucleolar organizer regions (AgNORs) and Ki-67. Exp Gerontol 37, 841-850

40. Rüschoff J, Neumann K, Contractor H, Plate K, Thomas C (1990) Assessment of nucleolar organizer regions by automatic image analysis in breast cancer: correlation with DNA content, proliferation rate, receptor status and histopathological grading. J Cancer Res Clin Oncol 116, 480-485

41. Munakata S, Hendricks JB (1994) A multilabeling technique for simultaneous demonstration and quantitation of $\mathrm{Ki}-67$ and nucleolar organizer regions (AgNORs) in paraffin-embedded tissues. J Histochem Cytochem 42, 789-793

42. Lorenzato M, Abboud P, Lechki C, Browarnyj F, O'Donohue MF, Ploton D, Adent JJ (2000) Proliferation assessment in brest cancer: a doublestaining technique for AgNORs quantification in MIB-1 positive cell especilly adapted for image cytometry. Micron 31, 151-159

43. Hofstädter F, Knüchel R, Rüschoff J (1995) Cell proliferation assessment in oncology. Virchows Arch 427, 323-341

44. Derenzini, M.; Trerè, D (1991) Standardization of interphase Ag-NOR measurement by means of an automated image analysis system using lymphocytes as an internal control. J Pathol 165, 337-341

45. Öfner D (2000) In situ standardised AgNOR analysis: a simplified method for routine use to determine prognosis and chemotherapy efficiency in colorectal adenocarcinoma. Micron 31, 161-164 